\title{
Bioavailability of Prednisolone Tablets
}

\author{
Aabrey V. Tembo, ${ }^{1,2}$ Margarete R. Hallmark, ${ }^{1}$ Ermelinda Sakmar, ${ }^{1}$ \\ Hannelore G. Bachmann, ${ }^{1}$ Donaid J. Weidler, ${ }_{9}{ }^{1}$ and John G. Wagner ${ }^{1,3}$
}

Received June 16, 1976-Final Dec. 2, 1976

\begin{abstract}
Two four-treatment crossover studies were performed using 12 adult male volunteers in each with seven different commercially available prednisolone tablets. Plasma samples were assayed for prednisolone by a radioimmunoassay method. Statistical analyses of the data, by analysis of variance for crossover design (ANOVA), showed no significant differences among the treatment averages at any of the sampling times except at 0.25 and $4 \mathrm{hr}$ in one of the siudies. There were also no significant differences among the trearment averages for peak plasma level, time of peak plasma level, area $0-12 \mathrm{hr}$, area $0-24 \mathrm{hr}$, and the half-life of elimination of prednisolone. We conclude that the average plasma concentrations of prednisolone are superimposable in a statistical sense and that the tablets tested are bioequivalent. Results of dissolution studies of six tablets of each of the seven lots of prednisolone tablets, using deaerased water in the spin filter apparatus, are presented.
\end{abstract}

KEY WORDS: prednisolone bioavailability; prednisolone radioimmunoassay; prednisolone plasma concentrations; elimination half-life of prednisolone; in vitro rate of dissolution of prednisolone from tablets.

\section{INTRODUCTION}

Prednisolone, 11ß,17,21-trihydroxypregna-1,4-dien-3,20-dione, is a potent corticosteroid that is offered for the palliative treatment of rheumatoid arthritis and various other diseases. Partly because of the low solubility of the drug (1), the Ad Hoc Committee on Drug Product Selection

This work was performed pursuant to Contract 223-75-3033, DHEW/Public Health Service, Food and Drug Administration, Rockville, Maryland, and was supported in part by Public Health Service Grant 5-P11-GM15559.

${ }^{1}$ College of Pharmacy and Upjohn Center for Clinical Pharnacology, The University of Michigan, Ann Arbor, Michigan 48109.

${ }^{2}$ Present address: Ministry of Health Lilongwe, Malawi.

${ }^{3}$ Address correspondence to Dr. John G. Wagner, Upjohn Center for Clinical Pharmacology, The University of Michigan Medical Center, Arn Arbor, Michigan 48109.

(C) 1977 Plenum Publishing Corp., 227 West 17 th Street, New York, N.Y. 10011 . To promote freer access to published material in the spirit of the 1976 Copyright Law, Plenum sells reprint articles from all its journals. This availability underlines the fact that no part of this publication may be reproduced, siored in a retrieval system, or transmitted, in any form or by any neans, electronic, thechanical, photocopying, microflming, recording, or otherwise, without writen permission of the publisher. Shipment is prompt; rate per articie is $\$ 7,50$. 
of the Academy of General Practice of Pharmacy included prednisolone in a list of drugs susceptible to bioavailability problems (2). Since then very few studies have appeared in the literature reporting the biological availability of prednisolone; most of these were recently reviewed in a monograph on prednisolone (3). The reviewers noted that with the exception of one study (4) all studies suffer from a number of serious experimental defects. The investigators, in these reports either have used high doses of prednisolone and failed to follow plasma levels of the drug for more than two half-lives with an insensitive colorimetric assay method (5), or have used a nonspecific assay and also failed to use the recommended crossover experimental design (6), or have studied sustained release of enteric-coated preparations (7-10). In view of the limited information on the in vivo availability of the corticosteroid following the administration of single, low doses of prednisolone in the form of compressed tablets, the studies to be reported were done. This article reports the results of two four-treatment crossover studies utilizing seven different, commercially available tablets of prednisolone.

\section{EXPERIMENTAL}

\section{Test Products}

The prednisolone tablets studied were obtained from the open market by the Food and Drug Administration, who reported to the authors that the tablets had the following average percentage of declared potency (SD in parentheses): Mc, 98.6 (3.12); St, 103.2 (2.33); Re, 98.3 (2.51); U, 98.9 (1.21); R, 105.7 (3.91); ST, 99.0 (3.00); O, 94.3 (2.50). The code letter(s) are the first one or two letters of the names of the manufacturers, and lot numbers are given in the footnote to Table $\mathrm{I}$.

\section{In Vitro Studies}

The spin filter apparatus of Shah et al. (12) was used to perform in vitro dissolution rate studies. All the studies were performed at $37^{\circ} \mathrm{C}$, using 1 liter of deaerated water as the dissolution medium. The dissolution studies on the same tablets are being repeated in $0.1 \mathrm{~N}$ hydrochloric acid using goldplated equipment, but these results will be reported in a separate communication. The stirrer speed was maintained at $400 \mathrm{rpm}$ for a period of $30 \mathrm{~min}$ and then it was changed to $800 \mathrm{rpm}$ until a constant absorbance reading was attained. The constant absorbance value could be interpreted as the percentage of label dissolved in infinite time. Since ultraviolet-absorbing material in the tablet, other than prednisolone, may contribute to the percentage of labeled amount of prednisolone dissolved and/or the prednisolone in the 
tablet may not all be released in a water system, the data are presented as "mean percentage of infinity dissolved," which is defined as the "mean percentage of label dissolved to an arbitrary time $t$ divided by the mean percentage of label dissolved in infinite time."

\section{Subjects}

In each study, 12 adult male volunteers with no known disease, who weighed between 54 and $95 \mathrm{~kg}$ and were between 21 and 33 years of age were selected. Six of the 12 subjects were common to both studies. The subjects had good venous systems in their arms to facilitate blood sampling. Before each subject could be included in the study, a complete physical and routine blood analysis and urinalysis were carried out. As a screening procedure, values for the following tests were required to be in the normal range: chloride, $\mathrm{CO}_{2}$, potassium, sodium, $\mathrm{BUN}$, glucose, total protein, albumin, calcium phosphorus, cholesterol, uric acid, creatinine, total bilirubin, alkaline phosphatase, LDH, SGOT, white cell count, hematocrit, hemoglobin, red cell count, and plasma 17-OHCS. Informed consent was obtained from all subjects.

A recent drug history was taken for each prospective subject. All subjects participating in the studies received no barbiturates or other enzyme-inducing agents for a period of 30 days preceding initiation of the studies, and none concurrent with them. They received no other medication or alcoholic beverages for a period of 7 days before initiation of the studies, and none during the study periods. After screening and acceptance for the studies, the subjects were assigned numbers and their body weight, age, height, race, and body build were recorded. ${ }^{4}$

\section{Treatment Schedule and Doses}

The subjects started fasting at 10 P.M. the night before administration of prednisolone. At 11 P.M. that night, each subject took orally $1.0 \mathrm{mg}$ dexamethasone (as two tablets of Decadron, $0.5 \mathrm{mg}$ ) to suppress endogenous cortisol secretion. Suppression of endogenous cortisol was necessary because cortisol cross-reacts with the prednisolone antiserum used in the radioimmunoassay. Dexamethasone does not cross-react with the prednisolone antiserum.

Within $1 \mathrm{hr}$ after arising, on the first day of the studies, each subject drank $240 \mathrm{ml}$ of water. At time zero, the subjects ingested $10 \mathrm{mg}$ of prednisolone with $180 \mathrm{ml}$ of water. The tablets were swallowed whole and not fractured or chewed before being swallowed. No food or beverages were

\footnotetext{
${ }^{4}$ The vital statistics of the subjects and all plasma concentrations measured in the two studies have been forwarded to the editor of this Journal to be placed in a repository.
} 
Table 1. Treatment Schedule

\begin{tabular}{cccccccc}
\hline & & & \multicolumn{5}{c}{ Time periods } \\
\cline { 6 - 7 } Study & Subjects & Group & Week I & Week II & Week III & Week IV \\
\hline 2 & $1,2,3$ & 1 & $\mathrm{Mc}^{a}$ & $\mathrm{St}$ & $\mathrm{U}$ & $\mathrm{Re}$ \\
& $4,5,6$ & 2 & $\mathrm{St}^{b}$ & $\mathrm{Re}$ & $\mathrm{Mc}$ & $\mathrm{U}$ \\
& $7,8,9$ & 3 & $\mathrm{Re}^{\mathrm{c}}$ & $\mathrm{U}$ & $\mathrm{St}$ & $\mathrm{Mc}$ \\
3 & $10,11,12$ & 4 & $\mathrm{U}^{d}$ & $\mathrm{Mc}$ & $\mathrm{Re}$ & $\mathrm{St}$ \\
& $1,2,3$ & 1 & $\mathrm{R}^{e}$ & $\mathrm{ST}$ & $\mathrm{O}$ & $\mathrm{U}$ \\
& $4,5,6$ & 2 & $\mathrm{ST}^{f}$ & $\mathrm{U}$ & $\mathrm{R}$ & $\mathrm{O}$ \\
& $7,8,9$ & 3 & $\mathrm{U}^{d}$ & $\mathrm{O}$ & $\mathrm{ST}$ & $\mathrm{R}$ \\
& $10,11,12$ & 4 & $\mathrm{O}^{8}$ & $\mathrm{R}$ & $\mathrm{U}$ & $\mathrm{ST}$ \\
\hline
\end{tabular}

${ }^{a} \mathrm{Mc}=\mathrm{C} . \mathrm{T}$. prednisolone, $5 \mathrm{mg}$ (McKesson, lot 3J215).

${ }^{b} \mathrm{St}=\mathrm{C} . \mathrm{T}$. prednisolone, $5 \mathrm{mg}$ (Stanley, lot 108-303).

${ }^{c} \mathrm{Re}=\mathrm{C} . \mathrm{T}$. prednisolone, $5 \mathrm{mg}$ (Rexall, lot C41913).

${ }^{d} \mathrm{U}=$ Delta-Cortef, $5 \mathrm{mg}$ (Upjohn, lot $945 \mathrm{CB}$ ).

${ }^{\complement} \mathrm{R}=\mathrm{C} . \mathrm{T}$. prednisolone, $5 \mathrm{mg}$ (Rondex, lot 37111 ).

${ }^{\prime} \mathrm{ST}=\mathrm{C} . \mathrm{T}$. prednisolone, $2.5 \mathrm{mg}$ (Stanley, lot 63402).

${ }^{8} \mathrm{O}=$ C.T. prednisolone, $5 \mathrm{mg}$ (Ormont, lot 151-6020).

permitted until $4 \mathrm{hr}$ after dosing with prednisolone. From $4 \mathrm{hr}$ after dosing with prednisolone, food and beverages were allowed ad libitum. Eight hours after the administration of prednisolone, the subjects were given another $0.5 \mathrm{mg}$ tablet of dexamethasone to continue the suppression of hydrocrotisone. A washout period of 1 week was allowed between treatments, a period of 2 months separated the two studies. The treatment schedules that were used in the two studies are shown in Table $I$.

\section{Blood Sampling}

Fifty milliliters of blood was taken from the forearm vein just prior to dosing with prednisolone (time zero). A dilution of the 0 -hr plasma was used in the construction of the calibration plot for the prednisolone radioimmunoassay. Subsequently, $10 \mathrm{ml}$ of whole blood was drawn at $0.25,0.5,1,2$, $3,4,6,8,12$, and $24 \mathrm{hr}$ after dosing with prednisolone. Each blood sample was centrifuged shortly after collection; the plasma was quick-frozen and kept in the frozen state $\left(-20^{\circ} \mathrm{C}\right)$ until just prior to assay.

\section{Assay Method}

Plasma samples obtained in Prednisolone Study No. $2^{5}$ were analyzed by using the following procedure, using antiserum supplied by Dr. J. C. K.

${ }^{5}$ Prednisolone Study No. 1 was that reported by Sullivan et al. (4). 
Loo. The samples were diluted so that $1 \mathrm{ml}$ of the diluted plasma contained between 0.4 and $10 \mathrm{ng}$ of drug. Usually unknown plasma samples were diluted 1:50 (same as in preparation of standard curve), but on reassay some had to be diluted $1: 10$ to get the concentration in range of the standard curve. One milliliter of diluted 0 -hr plasma was spiked with $0,0.4,0.8,2,4$, 6 , and $10 \mathrm{ng}$ of cold prednisolone for the binding curve. One milliiter of the diluted spiked plasma was extracted with $7 \mathrm{mi}$ of dichloromethane for $5 \mathrm{~min}$ on a mechanical shaker. The sample was centrifuged and the aqueous phase was aspirated. A $5-\mathrm{ml}$ aliquot of the organic phase was transferred to a disposable culture tube and evaporated to dryness under a stream of nitrogen. To the dried tube was added $50 \mu \mathrm{l}$ of absolute ethanol (wash sides), followed by $10 \mu 1$ of $\left[{ }^{3} \mathrm{H}\right]$ prednisolone. One milliliter of saline phosphate buffer was then added (wash sides) followed by $10 \mu$ l of a solution of the antiserum of Loo. The mixture was vortexed and incubated in a $37^{\circ} \mathrm{C}$ water bath for $15 \mathrm{~min}$. At the end of the incubation time, the sample was placed in an ice bath and $0.5 \mathrm{ml}$ of cold dextran-coated charcoal $(5 \%$ charcoal, $0.5 \%$ dextran $T_{70}$ ) was added. The sample was allowed contact with the charcoal suspension for exactly 10 min and then was centrifuged at $0^{\circ} \mathrm{C}$ and $2000 \mathrm{rpm}$ for $15 \mathrm{~min}$. The supernatant was quickly decanted into a scintillation vial containing $10 \mathrm{ml}$ of Unogel and counted for $10 \mathrm{~min}$.

The method of Sullivan et al. (4) was used to assay all samples obtained in Prednisolone Study No. 3, using antiserum of W. A. Colburn. Plasma samples were diluted to an appropriate degree so that $1 \mathrm{ml}$ of diluted plasma contained 2-20 ng of drug. Usually unknown plasma samples were diluted $1: 25$ (same as in preparation of the standard curve), but on reassay some had to be diluted $1: 10$ to get the concentration in the range of the standard curve. The standard curve was constructed from diluted (1:25) 0 -hr plasma that was spiked with $0,2,4,6,10$, and $20 \mathrm{ng}$ of unlabeled prednisolone.

All plasma concentrations of prednisolone were obtained by inverse estimation using the parameters of the least-squares line drawn through a logistic-logarithmic plot as indicated in

$$
\ln y=\ln \left[100-\frac{B(X)}{B(0)} \times 100\right] /\left[\frac{B(X)}{B(0)} \times 100\right]=S \times \ln C+\ln Q
$$

where $B(0)$ represents the percent-bound value when there was no prednisolone added to plasma, $B(X)$ represents the percent bound in the presence of prednisolone, $S$ is the slope of the line, $C$ is the concentration of prednisolone $(\mathrm{ng} / \mathrm{ml})$, and $\ln Q$ is the intercept of the regression line fitted to the data. Figure 1 represents the calibration curve for Prednisolone Study No. 2. The authors have evidence which clearly shows that this method of estimating prednisolone levels is superior to the method of Sulivan et al. (4) 


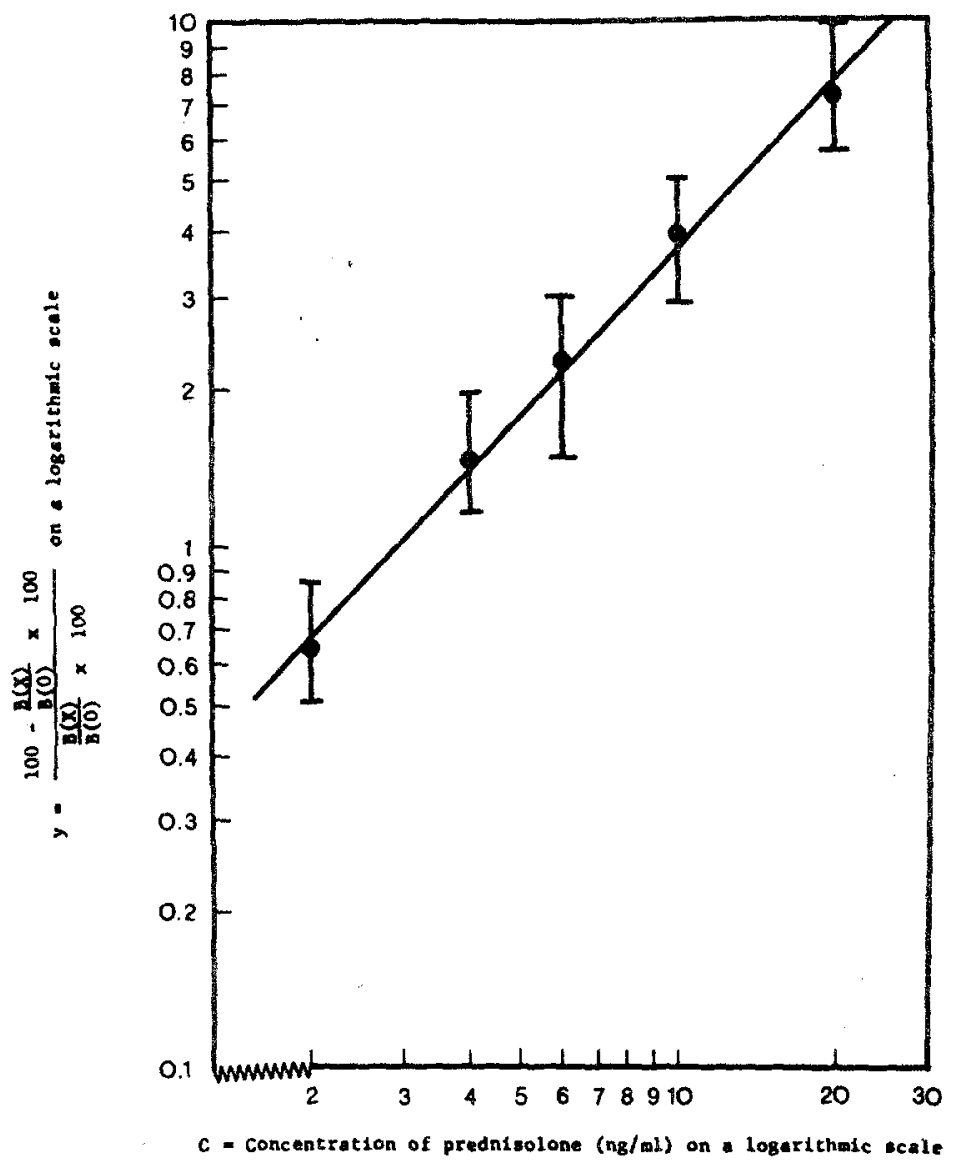

Fig. 1. Calibration data for prednisolone radioimmunoassay obtained by spiking diluted 0-hr plasma of the 12 subjects in Prednisolone Study No. 2. Circles represent $e^{\sqrt{\ln y}}$ values, where $\overline{\ln y}$ represents the average natural logarithms of the function shown on the ordinate scale for the 12 subjects. The bars mark off the range of values for the 12 subjects. The regression line has the equation in $y=0.8853 \ln C+0.4209$ and is based on 72 points. (See text for meaning of $y$.)

because it provides less bias in the calculated prednisolone concentrations. The authors would like to caution other investigators who work with radioimmunoassays that just because a logistic-logarithmic calibration plot works best for estimating plasma prednisolone levels, no inference is intended as to the superiority of this plot over other methods of calculating plasma levels of other compounds. For instance, the authors have evidence which indicates that a logistic-logarithmic plot is quite inadequate for 
estimating plasma levels of either prednisone or digoxin. A detailed analysis of radioimmunoassay data for prednisolone, prednisone, and digoxin is given by two of the authors elsewhere (11).

\section{RESULTS AND DISCUSSION}

\section{In Vitro Studies}

Figure 2 shows the in vitro dissolution data obtained in the spin filter apparatus (12) for the seven tablets tested in vivo. Each point on each curve represents an average of six separate tablet determinations. There were marked differences in the in vitro rates of dissolution among the tablets. It is

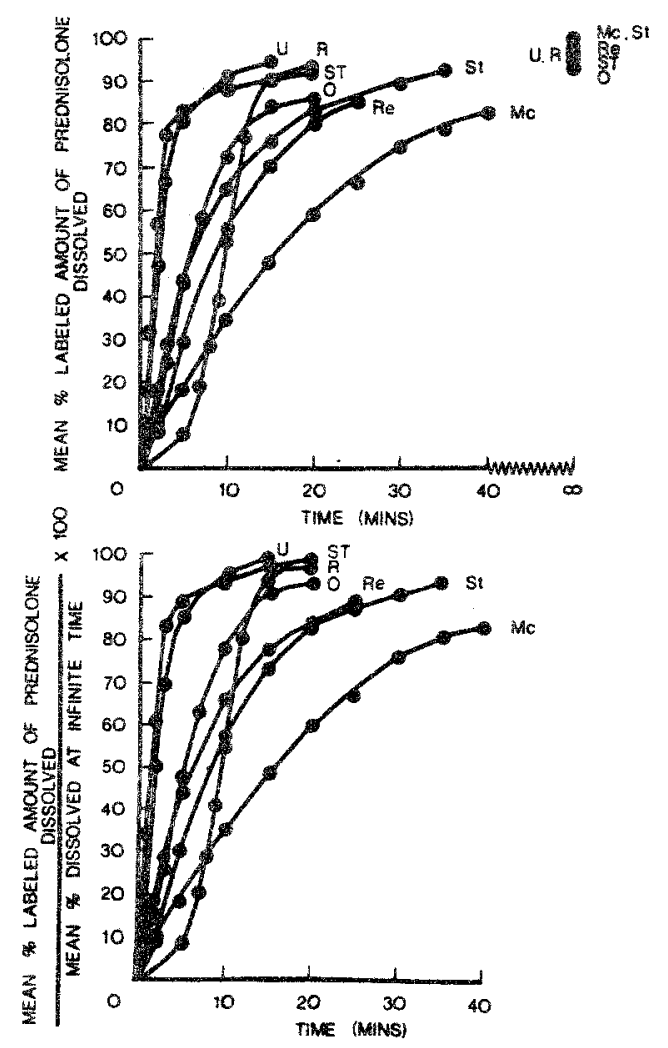

Fig. 2. Dissolution data for the seven different tablets used in Prednisolone Studies No. 2 and 3 in the spin filter apparatus of Shah et al. (12). See footnotes to Table I for key to different tablets. 
interesting to note that the $2.5 \mathrm{mg}$ and $5.0 \mathrm{mg}$ tablets (ST and St, respectively) of the same manufacturer released the drug at markedly different rates. The $2.5 \mathrm{mg}$ tablet dissolved more rapidly and displayed a hyperbolic type of release curve, while the $5.0 \mathrm{mg}$ tablet dissolved more slowly and displayed a sigmoid type of curve. All tablets were found to be equivalent with respect to availability in normal humans; therefore, for the tablets tested, absorption of prednisolone does not appear to be dissolution-rate controlled. All tablets apparently released prednisolone at an in vivo rate that was rapid enough so that this release did not rate-limit absorption in man.

\section{Assay Error}

In Prednisolone Study No. 2 antiserum of J. C. K. Loo was utilized and the standard curve (Fig. 1) is based on 72 points (the 12 subjects' 0 -hr plasma spiked at $0.4,0.8,2,4,6$, and $10 \mathrm{ng}$ prednisolone per milliliter of plasma).

The regression equation was

$$
\widehat{\ln y}=0.8853 \ln C+0.4209
$$

The concentrations of prednisolone in "unknown" plasmas were estimated by means of the rearranged form of equation 2 , namely,

$$
\hat{C}=e^{(\ln y-0.4209) / 0.8853}
$$

where $\ln y$ is given by the middle portion of equation 1 .

The coefficients of variation calculated from the inversely estimated concentrations $(\hat{C})$, using the $12 \ln y$ values at each concentration, were $17.9 \%, 11.8 \%, 13.1 \%, 14.6 \%, 14.0 \%$, and $20.3 \%$ for the known standard concentrations $\left(C_{s}\right)$ of $0.4,0.8,2,4,6$, and $10 \mathrm{ng} / \mathrm{ml}$, respectively. So-called bias values may be calculated from the mean estimated concentrations $\left(\hat{C}_{m}\right)$ using

$$
\text { bias value }=\left[\frac{\hat{C}_{m}-C_{s}}{C_{s}}\right] \times 100
$$

The observed bias values were $1.3 \%,-3.6 \%, 6.5 \%, 7.3 \%, 0.3 \%$, and $-2.1 \%$, respectively, for the concentrations in the same order.

In Prednisolone Study No. 3, antiserum of W. A. Colburn was utilized and a similar standard curve to that shown in Fig. 1 was obtained. The standard curve for this study was based on spiking the 0 -hr plasmas of subjects $1-6$ at $2,4,6,10$, and $20 \mathrm{ng}$ prednisolone/ml plasma. Thus the standard curve was based on 30 points. This was done since in Prednisolone Study No. 2 the logistic-logarithmic equation based on the data from subjects 1-6 was essentially identical to that based on subjects 1-12. 
Because the antiserum of W. A. Colburn was less sensitive than that of J. C. $\mathrm{K}$. Loo, the logistic-logarithmic equation was different and is shown as

$$
\widehat{\ln y}=1.0593 \ln C-1.1214
$$

The coefficients of variation estimated from the inversely estimated concentrations (as above) were $20.5 \%, 21.0 \%, 19.8 \%, 22.9 \%$, and $26.3 \%$ for actual concentrations of $2,4,6,10$, and $20 \mathrm{ng} / \mathrm{ml}$, respectively, and the bias values, calculated from the means, were $-2.0 \%, 4.3 \%, 8.2 \%, 7.0 \%$, and $3.5 \%$, respectively, for concentrations in the same order.

The calibration data for each subject in each study were collected on a different day; hence the above figures include both intra- and inter-day variation.

\section{Plasma Levels of Prednisolone}

The cross-reactivity of prednisolone, the prednisolone metabolite $20 \beta$ dihydroprednisolone, and cortisol with the antiserum of W. A. Colburn has been previously reported (13). We demonstrated that plasma concentrations of prednisolone were identical when assayed by the two antisera. Hydrocortisone cross-reacts with both antisera. Hence, in order to obtain a

Table II. Summary of Results of Prednisolone Study No. 2

\begin{tabular}{|c|c|c|c|c|c|}
\hline \multirow[b]{2}{*}{ Parameter } & \multicolumn{4}{|c|}{ Treatment averages } & \multirow{2}{*}{$\begin{array}{c}\text { Results of ANOVA test } \\
\text { - for among-treatment } \\
\text { averages }\end{array}$} \\
\hline & U & $\operatorname{Re}$ & $\mathrm{St}$ & $\mathrm{Mc}$ & \\
\hline \multicolumn{6}{|l|}{$\begin{array}{l}\text { Prednisolone plasma } \\
\text { concentration ( } \mathrm{ng} / \mathrm{mi})\end{array}$} \\
\hline $0.25 \mathrm{hr}$ & 71.7 & 46.3 & 50.8 & 31.2 & $\operatorname{NS}(0.05<p<0.10)$ \\
\hline $0.50 \mathrm{hr}$ & 157. & 146. & 135. & 136. & $\mathrm{NS}(p>0.25)$ \\
\hline $1.0 \mathrm{hr}$ & 240 & 228. & 217. & 211. & $\operatorname{NS}(p>0.25)$ \\
\hline $2.0 \mathrm{hr}$ & 205. & 206. & 209. & 200. & $N S(p>0.25)$ \\
\hline $3.0 \mathrm{hir}$ & 179. & 167. & 174. & 163. & NS $(p>0.25)$ \\
\hline $4.0 \mathrm{hr}$ & 153. & 128. & 143. & 144. & NS $(0.10<p<0.25)$ \\
\hline $6.0 \mathrm{hr}$ & 90.6 & 90.6 & 87.8 & 89.5 & NS $(p>0.25)$ \\
\hline $8.0 \mathrm{hr}$ & 53.2 & 45.4 & 50.7 & 49.1 & $\operatorname{NS}(p>0.25)$ \\
\hline $12.0 \mathrm{hr}$ & 17.3 & 15.6 & 17.8 & 17.1 & NS $(p>0.25)$ \\
\hline $24.0 \mathrm{hr}$ & 2.35 & 1.68 & 3.26 & 2.00 & NS $(0.1<p<0.25)$ \\
\hline Peak plasma level $(\mathrm{ng} / \mathrm{ml})$ & $25 \%$ & 238. & 238. & 232. & NS $(p>0.25)$ \\
\hline $\begin{array}{l}\text { Time of peak plasma } \\
\text { level (hr) }\end{array}$ & & & 13 & & NS $(n>095)$ \\
\hline Area $0-12 \mathrm{hr}$ & 1.42 & 1.25 & 1.13 & 1.50 & NS $(p>0.25)$ \\
\hline $\begin{array}{l}{[(\mathrm{ng} / \mathrm{ml}) \times \mathrm{hr}]} \\
\text { Area } 0-24 \mathrm{hr}\end{array}$ & 1246 & 1129 & 1187. & 1157 & NS $0.10<p<0.25$ ) \\
\hline $\begin{array}{l}{[(\mathrm{ng} / \mathrm{ml}) \times \mathrm{hr}]} \\
\text { Half-life }(\mathrm{hr})\end{array}$ & $\begin{array}{r}1364 . \\
2.55\end{array}$ & $\begin{array}{r}1233 . \\
2.60\end{array}$ & $\begin{array}{r}1314 . \\
2.77\end{array}$ & $\begin{array}{l}1271 . \\
2.62\end{array}$ & $\begin{array}{l}\mathrm{NS}(0.10<p<0.25) \\
\mathrm{NS}(p>0.25)\end{array}$ \\
\hline
\end{tabular}


more specific assay for prednisolone, it was necessary to suppress adrenal function with dexamethasone.

The average plasma concentrations of prednisolone following the four different treatments studied in Prednisolone Study No. 2 are summarized in Table II. There were no significant differences among the treatment average plasma concentrations at any sampling time. There were no significant differences among the treatment averages for peak plasma concentration, area $0-12 \mathrm{hr}$, area $0-24 \mathrm{hr}$, or the apparent half-life of elimination of prednisolone. The coefficients of variation of the averages shown in Table II are given in Table III.

The average plasma concentrations of prednisolone following the oral administration of the four treatments studied in Prednisolone Study No. 3 are summarized in Table IV. There were statistically significant differences among the treatment average plasma concentrations at 0.25 and $4 \mathrm{hr}$, but not at all other sampling times. There were also no significant differences among the treatment averages for peak plasma concentration, area 0-12 hr, area $0-24 \mathrm{hr}$, or the apparent half-life of prednisolone. Table $\mathrm{V}$ gives the coefficients of variation of the averages shown in Table IV.

Another important consideration is the power of the analysis of variance. If the hypothesis that the means were equal was false, a so-called type

Table III. Coefficients of Variation of Treatment Averages Given in Table II

\begin{tabular}{|c|c|c|c|c|c|}
\hline \multirow[b]{2}{*}{ Parameter } & \multicolumn{4}{|c|}{$\begin{array}{l}\text { Coefficients of variation (\%) } \\
\text { for treatments }\end{array}$} & \multirow{2}{*}{$\begin{array}{c}\text { C.V.(\%) } \\
\text { from RMS } \\
\text { of ANOVA }\end{array}$} \\
\hline & $\mathrm{U}$ & $\operatorname{Re}$ & St & Mc & \\
\hline \multicolumn{6}{|l|}{ Plasma concentration $(\mathrm{ng} / \mathrm{ml})$} \\
\hline $0.25 \mathrm{hr}$ & 74.9 & 80.7 & 83.3 & 86.1 & 67.9 \\
\hline $0.50 \mathrm{hr}$ & 42.1 & 37.9 & 40.3 & 50.1 & 42.5 \\
\hline $1.0 \mathrm{hr}$ & 18.9 & 17.4 & 19.9 & 32.6 & 21.2 \\
\hline $2.0 \mathrm{hr}$ & 11.0 & 15.0 & 18.2 & 26.7 & 15.1 \\
\hline $3.0 \mathrm{hr}$ & 12.3 & 12.9 & 16.5 & 25.0 & 14.4 \\
\hline $4.0 \mathrm{hr}$ & 29.1 & 12.7 & 19.5 & 22.4 & 18.8 \\
\hline $6.0 \mathrm{hr}$ & 23.3 & 14.6 & 18.7 & 23.8 & 18.6 \\
\hline $8.0 \mathrm{hr}$ & 33.9 & 16.4 & 21.1 & 27.4 & 26.5 \\
\hline $12.0 \mathrm{hr}$ & 41.6 & 42.9 & 33.1 & 45.7 & 35.9 \\
\hline $24.0 \mathrm{hr}$ & 91.0 & 124. & 87.2 & 110. & 84.5 \\
\hline Peak plasma level (ng/ml) & 10.1 & 14.1 & 12.0 & 22.4 & 13.9 \\
\hline Time of peak plasma level $(\mathrm{hr})$ & 70.3 & 57.8 & 38.5 & 60.3 & 72.7 \\
\hline Area $0-12 \mathrm{hr}[(\mathrm{ng} / \mathrm{ml}) \times \mathrm{hr}]$ & 10.8 & 8.58 & 10.8 & 19.0 & 10.7 \\
\hline Area $0-24 \mathrm{hr}[(\mathrm{ng} / \mathrm{ml}) \times \mathrm{hr}]$ & 13.0 & 9.5 & 12.1 & 19.0 & 11.9 \\
\hline Half-life (hr) & 22.6 & 14.6 & 18.4 & 15.5 & 13.2 \\
\hline
\end{tabular}

${ }^{a}$ RMS = residual mean square.

${ }^{b}$ ANOVA = analysis of variance for crossover design. 
Table IV. Summary of Results of Prednisolone Study No. 3

\begin{tabular}{|c|c|c|c|c|c|}
\hline \multirow[b]{2}{*}{ Parameter } & \multicolumn{4}{|c|}{ Treatment averages } & \multirow{2}{*}{$\begin{array}{c}\text { Results of ANOVA test } \\
\text { for among-treatment } \\
\text { averages }\end{array}$} \\
\hline & $\mathbf{R}$ & $S T$ & $\mathrm{O}$ & $U$ & \\
\hline \multicolumn{6}{|l|}{$\begin{array}{l}\text { Prednisolone plasma } \\
\text { concentration }(\mathrm{ng} / \mathrm{ml})\end{array}$} \\
\hline $\begin{array}{l}0.25 \mathrm{hr} \\
0.50 \mathrm{hr} \\
1.0 \mathrm{hr} \\
2.0 \mathrm{hr} \\
3.0 \mathrm{hr} \\
4.0 \mathrm{hr} \\
6.0 \mathrm{hr} \\
8.0 \mathrm{hr} \\
12.0 \mathrm{hr} \\
24.0 \mathrm{hr}\end{array}$ & $\begin{array}{l}22.1 \\
106 . \\
223 \\
212 \\
178 \\
125 \\
71.1 \\
37.0 \\
10.4 \\
1.62\end{array}$ & $\begin{array}{l}86.9 \\
180 . \\
255 . \\
232 . \\
199 . \\
158 . \\
92.2 \\
45.7 \\
18.2 \\
4.34\end{array}$ & $\begin{array}{l}36.9 \\
167 . \\
257 . \\
228 . \\
182 . \\
138 . \\
76.4 \\
36.5 \\
13.1 \\
4.45\end{array}$ & $\begin{array}{r}47.2 \\
165.0 \\
234.0 \\
238.0 \\
202.0 \\
154.0 \\
83.7 \\
43.4 \\
12.6 \\
3.30\end{array}$ & $\begin{array}{l}0.025<p<0.05 \\
\text { NS }(0.05<p<0.1) \\
\text { NS }(p>0.25) \\
\text { NS }(p>0.25) \\
\text { NS }(p>0.25) \\
0.025<p<0.05 \\
\text { NS }(0.05<p<0.1) \\
\text { NS }(p>0.25) \\
\text { NS }(0.1<p<0.25) \\
\text { NS }(p>0.25)\end{array}$ \\
\hline $\begin{array}{l}\text { Peak plasma level (ng/ml) } \\
\text { Time of peak plasma } \\
\text { level (hr) }\end{array}$ & 240.0 & 262.0 & 263.0 & 254.0 & $\mathrm{NS}(p>0.25)$ \\
\hline $\begin{array}{l}\text { Area } 0-12 \mathrm{hr} \\
\quad[(\mathrm{ng} / \mathrm{ml}) \times \mathrm{hr}] \\
\text { Area } 0-24 \mathrm{hr}\end{array}$ & 1052. & 1307. & 1171. & 1242. & $\mathrm{NS}(0.05<p<0.1)$ \\
\hline $\begin{array}{l}\qquad(\mathrm{ng} / \mathrm{mi}) \times \mathrm{hr}] \\
\text { Half-life }(\mathrm{hr})\end{array}$ & $\begin{array}{r}1124 \\
2.12\end{array}$ & $\begin{array}{r}1442 . \\
2.44\end{array}$ & $\begin{array}{l}1276 \\
2.30\end{array}$ & $\begin{array}{r}1337 . \\
2.26\end{array}$ & $\begin{array}{l}\operatorname{NS}(0.05<p<0.1) \\
\operatorname{NS}(p>0.25)\end{array}$ \\
\hline
\end{tabular}

II error ( $\beta$ error) would occur if the tested hypothesis was accepted when it was false. The probability of rejecting the tested hypothesis when it was false is called "the power of the test against a specified alternative" and is denoted as $1-\beta$. For example, if $1-\beta=0.8$, then the chances are 0.8 out of 1.0 of detecting the specified difference in means. Table VI lists values of $1-\beta$ which were calculated, using the coefficients of variation in the last columns of Tables III and V, by the method of Dixson and Massey (14) as illustrated for crossover studies by Wagner (15). Calculations were made for both a $20 \%$ and a $30 \%$ difference in extreme means with $\alpha=0.05$. As is usual in such evaluations of most bioavailability data, the $1-\beta$ values vary widelyin this case, from $<0.3$ to $>0.99$. The $1-\beta$ values are $\geq 0.8$, the usually desired values, for plasma concentrations at $1,2,3,4$, and $6 \mathrm{hr}$, peak plasma level, area $0-12 \mathrm{hr}$, area $0-24 \mathrm{hr}$, and half-life when the specified difference in extreme means is $30 \%$; nine of the values are $\geq 0.8$ when the specified difference in extreme means is $20 \%$. Our conclusion of bioequivalence (below) is principally based on the results of analyses of variance of the areas and the peak concentrations, and for these parameters there is excellent power usually with the $20 \%$ difference and always with the $30 \%$ difference. Although some readers may disagree with inclusion of Fig. 3 (discussed 
Table V. Coefficients of Variation of Treatment Averages Given in Table IV

\begin{tabular}{|c|c|c|c|c|c|}
\hline \multirow[b]{2}{*}{ Parameter } & \multicolumn{4}{|c|}{$\begin{array}{l}\text { Coefficients of variation (\%) } \\
\text { for treatments }\end{array}$} & \multirow{2}{*}{$\begin{array}{c}\text { C.V.(\%) } \\
\text { from RMS } \\
\text { of ANOVA }\end{array}$} \\
\hline & $\mathbf{R}$ & ST & 0 & $\mathrm{U}$ & \\
\hline \multicolumn{6}{|l|}{ Plasma concentration (ng/ml) } \\
\hline $0.25 \mathrm{hr}$ & 80.2 & 97.1 & 86.1 & 116. & 114. \\
\hline $0.5 \mathrm{hr}$ & 43.2 & 51.4 & 47.1 & 48.3 & 45.6 \\
\hline $1.0 \mathrm{hr}$ & 28.7 & 22.9 & 18.9 & 17.2 & 21.2 \\
\hline $2.0 \mathrm{hr}$ & 20.1 & 18.0 & 15.4 & 16.2 & 15.0 \\
\hline $3.0 \mathrm{hr}$ & 26.8 & 20.2 & 21.0 & 20.5 & 18.3 \\
\hline $4.0 \mathrm{hr}$ & 28.1 & 23.6 & 19.0 & 19.1 & 19.6 \\
\hline $6.0 \mathrm{hr}$ & 43.7 & 33.8 & 22.0 & 26.7 & 25.9 \\
\hline $8.0 \mathrm{hr}$ & 65.6 & 52.2 & 35.4 & 40.9 & 38.0 \\
\hline $12.0 \mathrm{hr}$ & 66.7 & 73.7 & 44,2 & 40.9 & 57.6 \\
\hline $24.0 \mathrm{hr}$ & 142. & 74.8 & 104. & 153. & 124. \\
\hline Peak plasma level (ng/ml) & 20.1 & 20.1 & 16.2 & 12.2 & 15.2 \\
\hline Time of peak plasma level $(\mathrm{hr})$ & 47.2 & 47.2 & 36.9 & 46.2 & 43.9 \\
\hline Area $0-12 \mathrm{hr}[(\mathrm{ng} / \mathrm{ml}) \times \mathrm{hr}]$ & 26.5 & 26.8 & 18.4 & 17.6 & 19.0 \\
\hline Area $0-24 \mathrm{hr}[(\mathrm{ng} / \mathrm{ml}) \times \mathrm{hr}]$ & 28.4 & 30.2 & 20.5 & 19.0 & 29.0 \\
\hline Half-life (hr) & 14.0 & 25.3 & 14.5 & 13.0 & 17.8 \\
\hline
\end{tabular}

${ }^{a} \mathrm{RMS}=$ residual mean square.

${ }^{b}$ ANOVA $=$ analysis of variance for crossover design.

Table VI. Values of the Power $(1-\beta)$ of the Analyses of Variance Using Coefficients of Variation in the Last Columns of Tables III and V and Extreme Means Differing by Both $20 \%$ and $30 \%$

\begin{tabular}{|c|c|c|c|c|}
\hline \multirow[b]{3}{*}{ Parameter } & \multicolumn{4}{|c|}{$1-\beta$} \\
\hline & \multicolumn{2}{|c|}{ Prednisolone Study No. 2} & \multicolumn{2}{|c|}{ Prednisolone Study No. 3} \\
\hline & $20 \%^{a}$ & $30 \%^{b}$ & $20 \%^{a}$ & $30 \%^{b}$ \\
\hline \multicolumn{5}{|l|}{ Plasma concentration $(\mathrm{ng} / \mathrm{ml})$} \\
\hline $0.25 \mathrm{hr}$ & $<0.3$ & $<0.3$ & $<0.3$ & $<0.3$ \\
\hline $0.50 \mathrm{hr}$ & $<0.3$ & 0.35 & $<0.3$ & $<0.3$ \\
\hline $1.0 \mathrm{hr}$ & 0.50 & 0.94 & 0.50 & 0.92 \\
\hline $2.0 \mathrm{hr}$ & 0.86 & $>0.99$ & 0.86 & $>0.99$ \\
\hline $3.0 \mathrm{hr}$ & 0.89 & 0.99 & 0.65 & 0.985 \\
\hline $4.0 \mathrm{hr}$ & 0.65 & 0.98 & 0.62 & 0.965 \\
\hline $6.0 \mathrm{hr}$ & 0.65 & 0.98 & 0.38 & 0.80 \\
\hline $8.0 \mathrm{hr}$ & 0.38 & 0.78 & $<0.3$ & 0.43 \\
\hline $12.0 \mathrm{hr}$ & $<0.3$ & 0.50 & $<0.3$ & $<0.3$ \\
\hline $24.0 \mathrm{hr}$ & $<0.3$ & $<0.3$ & $<0.3$ & $<0.3$ \\
\hline Peak plasma level (ng/ml) & 0.91 & $>0.99$ & 0.86 & $>0.99$ \\
\hline Time of peak plasma level (hr) & $<0.3$ & $<0.3$ & $<0.3$ & 0.33 \\
\hline Area $0-12 \mathrm{hr}[(\mathrm{ng} / \mathrm{ml}) \times \mathrm{hr}]$ & $>0.99$ & $>0.99$ & 0.65 & 0.978 \\
\hline Area $0-24 \mathrm{hr}[(\mathrm{ng} / \mathrm{ml}) \times \mathrm{hr}]$ & 0.978 & $>0.99$ & 0.50 & 0.942 \\
\hline Half-life (hr) & 0.94 & $>0.99$ & 0.72 & 0.986 \\
\hline
\end{tabular}

${ }^{a}$ Calculated for extreme means differing by $20 \%$ and specifically for means of $100,93.3,86.7$, and 80.

${ }^{b}$ Calculated for extreme means differing by $30 \%$ and specifically for means of $100,90,80$, and 70 using the method of Dixson and Massey (14). 


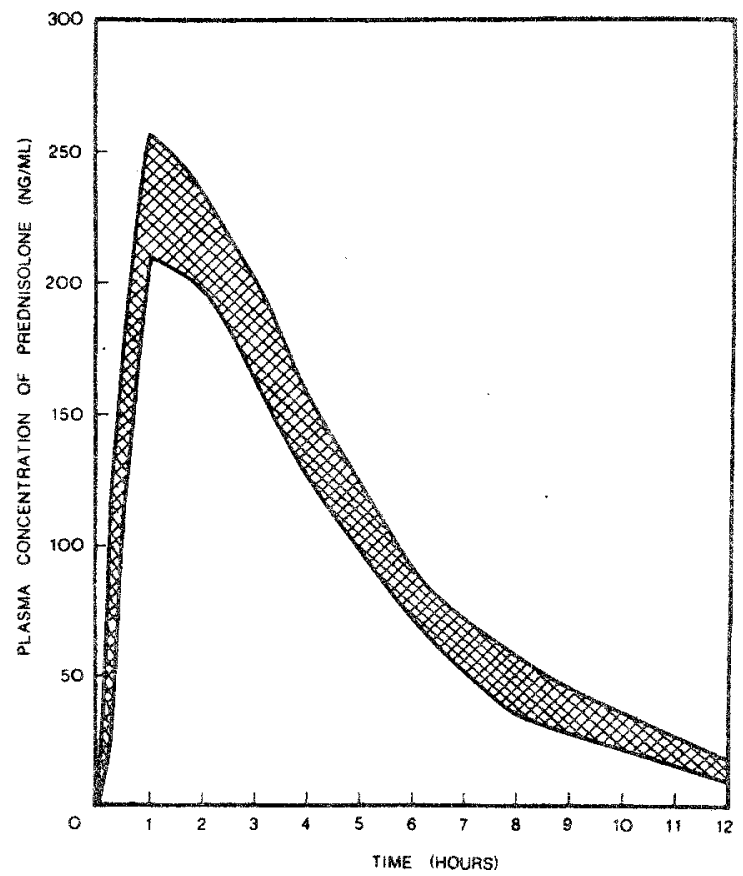

Fig. 3. Hatched area, bounded by the two solid lines, includes the average prednisolone plasma concentrations following oral administration of $10 \mathrm{ng}$ of prednisolone as nine different prednisolone tablets made by eight different manufacturers which were studied in Prednisolone Studies No. 1,2 , and 3 .

below), since it is a cross-study comparison involving different subjects, the authors wished to include it for clinically oriented readers, who, the authors believe, would also conclude bioequivalency.

Figure 3 summarizes the average prednisolone concentrations in all three prednisolone studies, where Prednisolone Study No. 1 was previously reported by Sullivan et al. (4). The plot includes data obtained with prednisolone tablets from nine different tablets made by eight different manufacturers. Iri light of the statistics reported for each of the three studies, the authors conclude that the average prednisolone concentrations are superimposable and that the nine different tablets tested are bioequivalent. The authors would like to caution that this conclusion not be extrapolated to all marketed prednisolone tablets.

\section{ACKNOWLEDGMENTS}

The authors would like to thank Mr. W. A. Colburn and Dr. R. H. Buller, The Upjohn Company, and Dr. J. C. K. Loo, Health Protection 
Branch, Health and Welfare Canada, Ottawa, Canada, for providing the antisera. We would also like to thank Dr. A. Shah, The Upjohn Company, for allowing us to use his spin filter apparatus for the in vitro dissolution studies reported in this article and Ms. Laura Tenhunen for typing the manuscript.

\section{REFERENCES}

1. W. L. Hayton, D. E. Guttman, and G. Levy. Effect of complex formation on drug absorption. XI. Complexation of prednisone and prednisolone with dialkylproprionamide and its effect on prednisone transfer through artificial lipoidal barrier. J. Pharm. Sci. 61:356-361 (1972).

2. An annotated list of drugs with potential for therapeutic inequivalence based on current evidence of drug product bioavailability inequivalence. J. Am. Pharm. Assoc. (NS) 13:279-280 (1973).

3. Prednisolone. J. Am. Pharm. Assoc. (NS) 16:143-146 (1976).

4. T. J. Sullivan, R. G. Stoll, E. Sakmar, D. C. Blair, and J. G. Wagner. In vitro and in vivo availability of some commercial prednisolone tablets. J. Pharmacokin. Biopharm. 2:29-41 (1974).

5. J. P. Isbister, J. Speros, and A. W. Steinbeck. The absorption of prednisolone B.P. as $5 \mathrm{mg}$ and $25 \mathrm{mg}$ tablets. Med. J. Aust. 56(1):1135-1136 (1969).

6. R. Tommasini, V. Mandelli, N. Passerini, and G. Tosolini. Research on the metabolism of

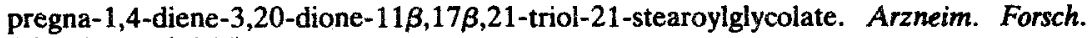
16:172-174 (1966).

7. J. English, J. Chakraborty, V. Marks, D. J. Trigger, and A. G. Thomson. Prednisolone levels in the plasma and urine: A study of two preparations in man. Br. J. Clin. Pharmacol. 2:327-333 (1975).

8. B. Hulme, V. H. T. James, and R. Rault. Absorption of enteric and nonenteric coated prednisolone tablets. Br. J. Clin. Pharmacol. 2:317-323 (1975).

9. J. G. Wagner, O. S. Carpenter, and E. J. Collins. Sustained action oral medication. I. A quantitative study of prednisolone in man, in the dog and in vitro. J. Pharmacol. Exp. Ther. 129:101-107 (1960).

10. P. F. D'Arcy, J. P. Griffin, J. S. Jenkins, W. F. Kirk, and A. W. C. Peacock. Sustainedrelease formulation of prednisolone administered orally to man. J. Pharm. Sci. 60:10281033 (1971).

11. A. V. Tembo, M. A. Schork, and J. G. Wagner. Statistical survey of "saturation analysis" calibration curve data for prednisolone, prednisone and digoxin. Steroids 28:387-403 (1976).

12. A. Shah, C. B. Peot, and J. F. Ochs. Design and evaluation of the rotating filter-stationary basket in vitro dissolution test apparatus. 1. Fixed fluid volume system. J. Pharm. Sci. 62:671-677 (1973).

13. W. A. Colburn and R. H. Buller. Radioimmunoassay for prednisolone. Steroids 21:833846 (1973).

14. W. J. Dixson and F. J. Massey, Jr. Introduction to Statistical Analysis, 2nd ed., McGrawHill, New York, 1957, p. 257.

15. J. G. Wagner. Fundamentals of Clinical Pharmacokinetics, Drug Intelligence Publications, Hamilton, 1ll., 1975, pp. 301-304. 